\begin{tabular}{lcl}
\hline Bentham OPEN & Open Medicine Journal \\
CrossMark & Content list available at: www.benthamopen.com/MEDJ/ & $\begin{array}{l}\text { Open } \\
\text { Medine } \\
\text { lournal }\end{array}$ \\
\hline
\end{tabular}

REVIEW ARTICLE

\title{
Analyzing the Demand Aspect of Sex Trafficking: Addressing the Market through Legislation and Tactics
}

Jessica A. Brautigam ${ }^{1}$, James B. Caruthers ${ }^{1}$, Ashley D. Knarr ${ }^{1}$, Todd J. Latiolais ${ }^{2}$, Alice Li ${ }^{3}$, Paul Osadebe $^{4}$ and Benjamin P. Rowe ${ }^{*, 5}$

${ }^{I}$ Children at Risk, 2900 Weslayan, Suite 400 Houston, Texas 77027, USA

${ }^{2}$ Center to End the Trafficking \& Exploitation of Children at Risk Houston, Texas 77027, USA

${ }^{3}$ Columbia Law School, 419 West $115^{\text {th }}$ Street \#52 New York, NY 10025, USA

${ }^{4}$ University of Texas School of Law Austin, Texas 78705, USA

${ }^{5}$ University of Houston Law Center Houston, Texas 77004, USA

Received: September 17, 2015

Revised: October 7, 2015

Accepted: October 27, 2015

Abstract: Human trafficking is a serious human rights violation. To combat human trafficking, the United States government and the State of Texas are shifting policies towards addressing the demand for commercial sex in an attempt to disrupt the trafficking "market." In order to better understand the sex trafficking market, we examine its components, specifically: suppliers, the supply of victims, and purchasers of victims. This article also provides an overview of federal and Texas anti-trafficking laws and how these laws address demand within their texts. Finally, the article provides an overview of some common demand reduction techniques.

Keywords: Commercial sex, Legislation, Sex trafficking, Tactics.

\section{INTRODUCTION}

For many years, human trafficking was primarily understood as an international problem; however, it has become increasingly clear in the recent years that this is a domestic issue as well. Texas is believed to be a particular hotspot for human trafficking due to its large cities, international airports, busy interstate highways, and shared border with Mexico. Texas was the second most common origin of calls to the National Human Trafficking Resource Center in 2014, with $9.6 \%$ of calls to the human trafficking hotline originating there [1]. The Human Trafficking Reporting System (HTRS) recorded 737 human trafficking-related incidents in Texas from January 1, 2007 to August 31, 2014, and the Federal Bureau of Investigation (FBI) Innocence Lost Initiative reported 444 child victims of sex trafficking from Texas-based task forces during the same period [2]. While trafficking is a serious problem in Texas, the state was also an early adopter of anti-trafficking legislation. In 2003, it became one of the first states in the country to codify human trafficking language.

As the anti-trafficking movement has grown over the past decade, understandings and approaches have evolved considerably. This article primarily addresses an approach known as combatting sex trafficking by addressing demand, which has been on the horizon in recent years and is quickly building momentum. We examine this issue by first providing a context for understanding the different actors in the market for sex trafficking and illegal commercial sex, then addressing the federal and Texas state legislative responses to combatting this problem, and last, providing a brief overview of commonly used tactics to combat demand.

\footnotetext{
* Address correspondence to this author at the University of Houston Law Center Houston, Texas 77004; Tel: +214-450-9797; E-mail: benjamin.P.rowe@gmail.com
} 


\section{THE MARKET FOR ILLEGAL COMMERCIAL SEX}

According to basic principles of economics, market prices are determined by the intersecting forces of supply and demand [3]. "Supply" refers to the quantity of product or service that can be offered in the market, while "demand" refers to the quantity of product or service that is desired by buyers. Both forces are necessary to sustain any market, including, in this case, the market for illegal commercial sex.

In the market for illegal commercial sex, there is no demand for trafficked individuals per se, (although there is a demand for particular types commercial sex that can only be provided by trafficked individuals, such as children). This is because demand for the service provided by a trafficked individual could, in many instances, just as easily be met by a non-trafficked individual. Any demand for illegal commercial sex is therefore inextricable from a general demand for sex trafficking.

The tangled relationship between demand for sex trafficking and demand for illegal commercial sex has led to the importance of demand reduction being recognized by the U.S. government. In 2013, the U.S. State Department's Trafficking in Persons Report stated, "If there were no demand for commercial sex, sex trafficking would not exist in the form it does today. This reality underscores the need for continued strong efforts to enact policies and promote cultural norms that disallow paying for sex" [4]. A similar perception in Texas has led to the development of the state's Human Trafficking Prevention Task Force. The task force is made up of representatives from the offices of the governor and attorney general, among others, to study the "social and economic factors that create a demand for the labor or services that victims of human trafficking are forced to provide" [5]. On the local level, this has resulted in increased efforts by law enforcement to target buyers in some jurisdictions.

\section{Overview of Suppliers: Pimps/Traffickers/Market Facilitators}

A "pimp" is an individual who earns money through the facilitation of commercial sex transactions [6]. Other terms for such an individual include manager and market facilitator. The popular understanding of a "pimp," however, is more specific and refers to an individual who "controls the actions and lives off the proceeds of one or more women who work the streets" [6]. The legal distinction between pimping and trafficking is often blurry, although pimping generally becomes trafficking when "the threat or use of force, coercion, abduction, fraud, deception, abuse of power or vulnerability, or giving payments or benefits to a person in control of the victim" is present [6]. Additionally, a pimp who facilitates commercial sex transactions with a minor is always engaged in trafficking [7,8].

Research about pimps and traffickers has been limited and difficult due to the illegal nature of their work. According to a sample of incarcerated pimps, they are mostly, but not always, male and diverse in terms of race and level of education [6]. Although African-American offenders appear to constitute a disproportionately large percentage of arrested and convicted pimps and traffickers [6], it is unclear whether they are representative of all pimps or whether African-American offenders are more likely to be arrested and convicted. Reported entry points into pimping are varied and include family experience with pimping or prostitution, neighborhood context and community influence, transitioning from drug dealing, recruitment by women in prostitution, and mentorship by other pimps [40]. Female pimps can enter into pimping from formerly being prostituted individuals themselves [40]. They include madams or business partners, who manage activity within a structured brothel, women who traffic their children or other family members, women who help their sons or husbands with pimping, women who are complicit and peripherally involved in pimping, and "bottoms" women who work for a pimp and also recruit, train, and discipline other women who work for the pimp [7].

Traffickers are similarly diverse and have no standard profile, ranging from strangers to boyfriends to family members. At least $28 \%$ of traffickers worldwide are women, which makes trafficking one of the crimes with the highest proportion of female offenders [9]. Trafficking can range from a small, local operation to an organized crime operation involving a large number of victims [9]. While transnational trafficking rings do exist, the prevalence of organized crime involvement in transnational sex trafficking is currently not known.

Gangs are sometimes involved in pimping, providing protection for individuals in prostitution and sex trafficking. The overall frequency of gang involvement in pimping and trafficking is not known. While gangs and cartels have been identified as key actors in trafficking activity along the border, pimping is generally not considered to be a crime most commonly perpetrated by gangs or organized crime networks [6]. Instead, many pimps are organized in an informal social network, sharing or exchanging employees, resources, and information to avoid detection by law enforcement [6]. 
Some pimps manage massage parlors or other sexually oriented businesses, using them as fronts for underground prostitution. Other pimps can be highly mobile, frequently traveling to different cities around the country for purposes such as avoiding police crackdowns on prostitution, migrating to areas with large crowds, and capitalizing on the "newness" of their supply in a new city [6]. Additionally, pimps can have relationships with legal businesses, such as hotels, which facilitate their criminal behavior [6].

Pimps vary in the age and demographics of the individuals they recruit into prostitution. Some pimps recruit minors, while some avoid recruiting minors, citing ethical or pragmatic (i.e. believing that minors do not make as much money or that hiring minors would lead to arrest) reasons $[6,10]$. Pimps can recruit individuals through a "gorilla pimping" style, using violence or threats to coerce an individual into trading sex, or through a "finesse pimping" style, using nonphysical persuasion and manipulation such as engaging in romantic relationships with the women they are recruiting [6]. Both male and female pimps utilize "gorilla pimping" methods [7]. Pimps frequently impose rules and quotas on their workers and can punish rule-breaking through violence or other forms of coercion [6]. However, levels of coercion and exploitation can vary widely among pimps and managers [10, 11, 39].

\section{Overview of Supply: Sex Trafficking Victims \& Individuals in Prostitution}

Individuals in prostitution comprise a diverse population Age of entry and race vary considerably, as do reasons for entry into a life of prostitution. Reasons include economic need; homelessness; encouragement of family members, friends, or acquaintances; support for substance abuse habits; desire for social and emotional acceptance (particularly for transgender individuals); and continuation from other forms of commercial sex (such as stripping) [12]. Some individuals enter prostitution due to an inability to find any other job, others have previously held legitimate employment but found their wages insufficient to live on, and still others have legitimate employment and use prostitution as a supplemental source of income [13]. Some individuals in prostitution work for pimps, while others work independently, and individuals in prostitution can transition from working with pimps to working independently, or vice-versa [6].

Individuals in prostitution are generally divided into indoor prostitutes and street-based prostitutes. Indoor prostitution is characterized by solicitation and sexual exchange occurring off the street and includes individuals who work in brothels, in massage parlors, independently in their own homes, and as escorts. The percentage of individuals in street versus indoor prostitution is uncertain, although some have suggested that while street prostitution is more commonly studied, it constitutes a minority of overall prostitution [12]. Recent decades have seen increasing use of the Internet by individuals in prostitution in order to solicit buyers by posting ads, and use of the Internet is likely helping to expand the underground commercial sex market by providing a new venue to solicit prostitution [6].

Risks reported by individuals in street and indoor prostitution include law enforcement and arrest (including violence and assault by law enforcement), violence and coercion from pimps, and the possibility of abuse and violence from buyers [13]. Studies have suggested that non-trafficked individuals in indoor prostitution are less vulnerable to violence than individuals in street prostitution [12]. Individuals in street prostitution often face greater risk of contracting sexually transmitted diseases and problems associated with substance abuse [6]. Additionally, the stigma associated with prostitution, particularly street prostitution, is a source of stress to individuals [14].

Individuals who are trafficked for sex include both domestic individuals and migrants from other countries. The majority of sex trafficking victims are female, though 3\% of identified worldwide sex trafficking victims are male [15]. Migrants from other countries who are ultimately sex-trafficked may initially immigrate in the belief that they would find legal employment in the U.S. unrelated to commercial sex, only to end up under the control of sex traffickers and being forced or coerced into prostitution. Some other migrants may immigrate with the knowledge that they would be employed in the sex industry upon arriving in the U.S., but unexpectedly find themselves working in exploitative, abusive conditions [16].

\section{Overview of Demand: Sex Buyers}

In order to understand the market for illegal commercial sex and the state of demand in Texas, it is essential to have an accurate understanding of the buyers of commercial sex. Sex buyers are commonly referred to as "Johns," but this article defaults to more descriptive market terms such as "buyers" or "purchasers." Many analysts divide the different theories about the demographic, psychological, and criminal nature of sex buyers into what could be approximately described as the "peculiar man" and "ordinary man" theories [17]. The "peculiar man" theory asserts that men who purchase sex are distinct from non-buyers in significant, and usually negative ways [17]. This position typically 
contends that sex buyers are men of inferior psychological or moral character who are more likely than other men to engage in other forms of criminality, believe in rape myths which are considered predictors of likelihood to commit sexual assault, or prone to actually assaulting women [17]. Methods aimed at addressing this theory of the customers often focus on their status as sick or depraved individuals. Responses therefore often range from a focus on sexual addiction and anger management to calls for increased incarceration and incapacitation of Johns as potentially dangerous offenders.

On the opposite end of the spectrum, the ordinary man perspective proposes that there are few meaningful demographic or psychological differences between buyers and non-buyers. In this view, men who purchase sex are not necessarily troubled individuals with histories of mental illness or antisocial behavior, nor are they criminals who simply expanded their activities to the commercial sex market [17]. They are truly the "John Next Door." They are neighbors, school bus drivers, CEOs, lawyers, doctors, taxi drivers and more. This theory, when coupled with the old saying that prostitution is "the oldest profession" frequently leads to the assumption that a thriving commercial sex market is inevitable or that purchasing sex is a typical element of male sexuality. However, these assumptions are inaccurate because the vast majority of men both in the United States and abroad do not purchase sex. In the United States, only 16 percent of adult men have ever purchased sex and only 1 percent of those did so in the last year [17]. These numbers are even lower in other countries like the United Kingdom where the percentage is as low as 7 percent [18]. The percentages seem to indicate that the acceptance and patronization of prostitution is at least somewhat culturally determined and may not an unavoidable byproduct of society.

Despite the low rate of sex buying in various countries, research lends some credence to both the "peculiar man" and "ordinary man" ends of the spectrum. There is a well-documented group of buyers that has been termed "high frequency buyers" or "hobbyists" [17]. These are buyers that purchase habitually and continually and they are the ones that purchase the highest volume of commercial sex acts and thus provide the demand necessary to sustain the market. These buyers often congregate and discuss purchasing sex on online forums and review sites [19]. When these men meet online, they trade tips on avoiding police stings, review providers, and inform each other of places to purchase sex [19]. When compared to non-buyers and even less active buyers, this subpopulation tends to be whiter, richer, older, less likely to be married, more educated, more sexually liberal, more likely to believe that prostituted individuals enjoy their jobs, and more committed to participating in the commercial sex market [19]. When these men do have wives or regular partners, there is often a mismatch in sexual desire between these men and their significant other as they are likely to enjoy sex more than their partner or to enjoy a different type of sex [20]. Their higher social status, increased knowledge, and ability to pay for higher priced indoor prostitution largely insulates them from public shaming efforts, or criminal prosecution [20].

Many high frequency buyers seek the girlfriend experience or "GFE" in which the sex provider creates an illusion of a conventional relationship that is more intimate than other types of prostitution [19]. Although this experience is at least superficially more intimate than other types of prostitution, it is still purposefully limited by the transactional nature of the interaction. The seller seems more receptive to the buyer's attention, so the man feels less guilty about the exchange and it becomes easier for him to feel that the desire is mutual. However, unlike conventional relationships, the meetings still occur almost entirely on the man's terms and the woman has little power in the interaction [19].

Finally, there is another subset of customers with socially conservative attitudes that are judgmental toward prostituted individuals and more likely to enjoy violence and violent sexuality [17, 21]. Somewhat counterintuitively, it is not the men that have a consumerist or transaction-focused attitude toward sex that are most likely to exhibit these traits. Those most likely to pose a danger to prostituted women are those with "fragile masculinities" that may be purchasing sex due to lack of success with conventional relationships [21]. These men purchase sex in order to experience intimacy and to reinforce their masculinity and thus may act out through violence in order to assert control or when they become frustrated by a perceived lack of enthusiasm by the prostituted individual [21]. These men may judge women harshly for their sexuality and view themselves as good people [17]. At the same time, they are patronizing prostituted individuals. The conflict between the actions, behaviors, and self-concept of these men may lead them to blame the women they engage with for enticing them into violating their morals [17].This anger can lead to violence against prostituted individuals and these men may account for much of the violence against them [22].

On the other hand, most buyers purchase sex infrequently and in a way that's more influenced by the events in their lives than by inherent personality defects [17]. Purchasing sex is not part of the self-identity of these men. These men generally do not differ significantly from non-buyers in their demographics, attitudes, or propensity toward violence [17]. These men are probably the most likely to be picked up in reverse stings due to their inexperience with purchasing 
sex and possibly the most likely to be deterred from reoffending due to the shock of arrest, shaming, and possible jail time or John schools (these demand-reduction tactics will be discussed in greater detail later in this article) [23]. However, due to that same lack of sophistication, these customers are also more likely to be involved in street prostitution, rather than escort or indoor services [17]. Many of these first time or inexperienced buyers reported that they had no regular partner or not had sexual experiences within the past year, which implies that for many of these men, their purchasing was brought on by sexual frustration, rather than any type of pathology [17].

Overall, the research is clear in showing that there is more than one type of sex buyer. The buyer population is just as diverse as the non-buyer population and contains people who interact with the commercial sex market in a number of different ways. On the whole, the evidence seems to show that the "ordinary man" perspective is closer to being representative of most buyers, but that there is a sizeable subset of buyers that are more peculiar, more distinct from the general population and more dangerous to prostituted women.

\section{HUMAN TRAFFICKING AND DEMAND IN FEDERAL AND STATE LAW}

The United States passed its first piece of comprehensive anti-trafficking legislation in the year 2000, and states quickly began following suit. In particular, Texas was an early adopter and was one of the first two states to add human trafficking to its legislative framework. Laws have evolved considerably since that time, and the cutting edge of policy is to invigorate the focus on demand. The following section provides a brief overview of federal and state responses to the issue.

\section{The Trafficking Victims Protection Act}

The hallmark of federal human trafficking legislation in the United States is the Trafficking Victims Protection Act of 2000 (TVPA). The TVPA, for the first time, created a federal criminal offense for those who engaged in all forms of human trafficking, including both labor and sex trafficking. The TVPA defined and criminalized sex trafficking for anyone who by force, fraud or coercion recruited, harbored, transported, provided, or obtained a person for the purpose of a commercial sex act [7]. The TVPA also recognized that minors are an especially vulnerable population and criminalized sex trafficking of individuals under the age of eighteen without having to show force, fraud or coercion, and declared such an act a severe form of trafficking allowing for higher criminal penalties for those who prostituted minors [7]. Physical transportation from one location to another is not necessary for a crime to fall within the definition of human trafficking.

A major focus of the TVPA originally was to provide protections for foreign nationals trafficked in the United States. The TVPA allowed these individuals to apply to receive benefits and services if they had been brought into the country and then trafficked [7]. Additionally, the TVPA established the Interagency Task Force to Monitor and Combat Human Trafficking which is tasked with the duty to bring domestic and foreign agencies together to measure and monitor worldwide human trafficking [7]. The TVPA was the first step in recognizing that persons who have been trafficked and prostituted are victims and not criminals and that the true criminals were the ones who engaged in the trafficking activity [7].

Congress recognized that human trafficking is an evolving crime and required that the TVPA be reauthorized every few years in order to update the act so that it too could evolve to better combat human trafficking [24]. Many of the updates have dealt with combating international trafficking or labor trafficking; however, the TVPA along with other newer federal statutes have evolved to have stronger language around domestic trafficking as well [25 - 28$]$.

\section{The Trafficking Victims Protection Act and Demand}

The Trafficking Victims Protection Act (TVPA) has rarely been used to go after the buyers of commercial sex, though it has been long used to pursue the suppliers of victims [29]. The first known prosecution of buyers of minor commercial sex victims occurred in 2009 after a local task force including the United States Attorney's Office of the Western District of Missouri launched Operation Guardian Angel in which ads for underage prostituted individuals were placed online [30]. As a result of this operation, seven people were charged as sex traffickers for attempting to purchase sex from underage children [30].

The next known charge for buyers under the TVPA was in 2011 when a South Dakota task force replicated the Operation Guardian Angel approach by placing ads of underage children online [29]. Two individuals responded to the ads and were convicted of violating the TVPA in regards to sex trafficking of a minor [29]. They appealed their 
convictions arguing that simply purchasing sex does not make them sex traffickers and that the act only applied to the suppliers of trafficked victims. The $8^{\text {th }}$ Circuit Court of Appeals disagreed and stated that "obtained" in the TVPA applied to those who purchased sex as well as those who supplied trafficking victims and upheld the convictions [29]. Even after the $8^{\text {th }}$ circuit's, ruling there was still some confusion about who was a sex trafficker under the TVPA. Enter the Justice for Victims of Trafficking Act (JVTA).

\section{The Justice for Victims of Trafficking Act}

The Justice for Victims of Trafficking Act (JVTA) was authored by Texas Senator John Cornyn and championed in the House by Texas Representative Ted Poe. It is the most recent comprehensive anti-trafficking legislation at the federal level and was signed into law by President Obama in May of 2015. The JVTA is an attempt to address several concerns and clarify certain aspects of the TVPA. The chief concerns were to make sure buyers of sex trafficking victims are regarded as traffickers along with making sure domestic victims received access to services that were authorized for alien victims [31]. The JVTA also changes the way that restitution is paid to trafficking victims. The TVPA required that prosecutors determine what property was used directly in an act of trafficking in order to use forfeiture to get restitution for victims, while the JVTA allows prosecutors simply to show that certain assets were used in the crime, which eliminates the burden of finding direct traceability [31]. This will allow more funds to be available to victims for restitution. The JVTA also created a fund that will be financed by a special assessment for all persons convicted of trafficking, as well as other related offenses, which will be used to provide resources to victims [31]. The fund is estimated to bring in around $\$ 31$ million dollars per year to be spent on victim services [32].

\section{The Justice for Victims of Trafficking Act and Demand}

The JVTA redefines the TVPA definition of sex trafficking by adding the words "patronizes" or "solicits" to make it perfectly clear that one who buys sex from an underage minor or from someone who is under force, fraud, or coercion is a trafficker and subject to the penalties stated in the JVTA [31]. By changing the definition and making it clear that the law applies to buyers as well, a victim will now be able to sue her buyer under the civil suit provisions created under the TVPA. The JVTA also extends the time that a child victim is allowed to sue the trafficker to ten years after the victim turns eighteen, rather than a simple ten year limitation [31].

The JVTA also changes some fundamental policies on how buyers should be dealt with by law enforcement. The act directs the Attorney General to ensure that federal law enforcement is engaged in activities, programs, or operations involving the detection, investigation and prosecution of buyers [31]. The JVTA also leverages existing resources by directing federally funded law enforcement task forces that are part of the Innocence Lost National Initiative to focus on fighting demand for human trafficking through the investigation, arrest, and prosecution of persons who purchase sexual acts with human trafficking victims [31]. The key to these policy shifts is making sure that the buyer is included in law enforcement activities to address human trafficking.

The JVTA compels the Attorney General to make sure all training programs on human trafficking that are operated by the Department of Justice on the federal, state and local level include effective strategies for apprehending buyers, as well as training on how to identify and refer victims to appropriate services [31].

\section{Texas Legislation}

In 2003, Texas became one of the first two states in the country to add human trafficking to its statutory framework. Just as the federal approach to human trafficking has evolved over time, Texas has also made numerous changes to its laws in order to update its anti-trafficking policies. The Texas Penal Code generally follows the lead of federal law by allowing a human trafficking conviction if a person has transported, enticed, recruited, harbored, provided, or otherwise obtained another person by any means with the intent to force that person into labor; or by means of force, fraud or coercion causes a person to engage in a number of prostitution related crimes [8].

For child sex trafficking, the Texas statute recognizes that children are an especially vulnerable population and allows conviction without regard to force, fraud or coercion if the trafficker has caused a child to become a victim of any number of commercially sexual related offenses [8]. These include a wide range of offenses from prostitution all the way to sexual performance by a child [8]. The Texas statute does not allow a trafficker to claim as a defense that he did not know the child's age [8]. A conviction under the child sex trafficking statute results in a felony of the first degree with an applicable penalty of up to life in prison [33]. In the most recent legislative session, Texas established a Child Sex Trafficking Prevention Unit within the office of the governor to attempt to prevent child sex trafficking as 
well as identify victims and refer them to available services [34].

Despite the expanded criminalization of child exploiters, Texas has not fully embraced the federal approach of treating all minors engaged in prostitution as victims. Texas has no statute that prohibits the prosecution of a minor for a prostitution offense. However, through case law, a child under the age of fourteen may not be prosecuted as a prostitute because in Texas they cannot legally consent to have sex in the first place [35]. Texas prostitution laws do allow an affirmative defense to a prostitution prosecution if the victim can show that they have been trafficked [36].

\section{Texas Legislation and Demand}

A major step that any jurisdiction must take in order to reduce the demand for illegal commercial sex and sex trafficking is to first assess the extent of its demand problem. In Texas, the criminalization of buyers revolves largely around solicitation of children, commercially sexually exploitative crimes against children, and the purchase of prostitution. The agreement to purchase prostitution is a major component of the overall dataset of demand for illegal commercial sex, but due in part to the state's legislative framework, accurate data on arrests of these buyers is not readily available statewide. This complication stems from the fact that, unlike some states which have separate criminal offenses for buyers and sellers, Texas has a global prostitution statute which covers buyers and sellers under the same offense. Consequently, data requests from law enforcement in Texas will generally be unable to disaggregate prostitution offenses between buyers and the prostituted individuals. A simple disaggregation by gender could be done, but would not provide a complete picture because many jurisdictions may arrest a significant number of male prostitutes. Although Texas recently changed its prostitution laws to make two separate categories under prostitution for the buying and selling of illegal commercial sex, the state did not create a completely separate offense for patronizing a prostitute [37].

Another major component of a jurisdiction's approach to addressing demand is the manner in which its laws deter buyers. Currently, Texas law treats buyers and providers equally, and the purchase of sex is primarily a misdemeanor level offense. However, the crime progresses to a felony level offense upon a fourth conviction or if the individual solicited is a minor. Although the law treats buyers and sellers equally, law enforcement resources appear to be primarily focused on sellers. Basic prostitution data submitted by law enforcement to the Texas Department of Public Safety strongly suggests that prostitutes are much more likely to be arrested than buyers. Over 88,000 prostitution arrests were reported by participating agencies from 2000 to 2014, and only $26 \%$ of those arrests were of men [38]. Prostituted individuals are more likely than their buyers to come in contact with law enforcement and are therefore more likely to face enhanced penalties for repeat offenses.

The case is fairly easily made in Texas that buyers can also be prosecuted under the state's human trafficking laws. The penal code explicitly states that an individual commits the offense of trafficking in persons if he receives a benefit from participating in a venture that involves trafficking or engages in sexual conduct with a trafficked person [39]. Under these provisions, a buyer would be guilty of a second degree felony or a first degree felony if the purchased victim was a minor [40].

Texas lawmakers have attempted to give law enforcement the necessary tools to pursue those who are facilitating sex trafficking, including those who attempt to purchase sex from children. Decoy operations, discussed more fully in the section on law enforcement tactics, are a necessary tool for effectively arresting sex buyers. Texas law was recently expanded to ensure that buyers face felony level liability for attempting to purchase sex from an individual they believed to be a minor, even though in reality that individual was an adult decoy officer [34]. Although Texas law takes a strong stance against child exploitation, it did not formerly require a buyer of a prostituted child to register as a sex offender. The $84^{\text {th }}$ Texas Legislature updated the law so that if a buyer purchases a prostitute under the age of 18 they must now register as a sex offender [34].

\section{AN OVERVIEW OF LAW ENFORCEMENT TACTICS BEING USED TO ADDRESS DEMAND}

Law enforcement plays a key role in deterring the demand for sex trafficking and commercial sex. A variety of tactics are being implemented throughout the country with various degrees of success. This section will provide an overview of some of the most commonly used techniques with a particular emphasis on efforts in Texas.

\section{Reverse Stings Generally}

The "reverse sting" operation is the most commonly used tactic to attack demand for illegal commercial sex [41]. 
The term describes an undercover operation where officers pose as decoys waiting to be approached by buyers of commercial sex [42]. Reverse stings are conducted differently by different departments, but all involve a complicated scheme of decoys, surveillance, and arrest operations [42]. Approximately forty-six jurisdictions in Texas have reported conducting reverse sting operations [43]. There are generally three different types of reverse sting operations that a given jurisdiction may conduct: street level, web based, and brothel based [41].

\section{Street Level Reverse Stings}

Street level reverse prostitution stings were the most popular methods used throughout the 1990's and early 2000's, prior to the commercial sex industry moving to the internet [41]. The street level stings are still conducted but are typically conducted based on community demand or complaints [44]. The first street level type reverse stings were conducted in 1964 in Nashville, Tennessee [45]. The typical street level reverse sting is conducted in high-prostitution areas, where known providers are typically found. The timing of the sting will also be selected based on highprostitution times, which tend to be lunch time, after 5:00pm, and after bars close [44]. In order to prepare the streets for the prostitution sting, and to avoid conflict with local providers, local law enforcement will sometimes conduct a sting to arrest providers days before the reverse sting is conducted. This clears the streets of local providers, and sometimes their pimps, so that law enforcement can avoid their operation being discovered [44].

The decoy is the female officer that poses as a provider. The size of the operation depends on the availability of decoys and surveillance officers, orders from the Chief of police or department head, and how big the problem is at a given time [44]. Training and experience of the officers selected to conduct the reverse sting operation will vary from department to department. Some departments will not use any specific training techniques, while other larger departments have entire decoy training programs set up. Large agencies may also share their officers with smaller agencies that are unable to employ suitable decoy officers.

A small operation will have one to two decoy officers surrounded by a team of male officers for surveillance and apprehension purposes. Occasionally, there is a department jail arrest van nearby where the buyers are processed [44]. The decoy is almost always wired for recording of conversations, and there is often clear surveillance video [42]. The video surveillance is used for both safety purposes, and to record gestures, such as nodding of the head, to make an agreement for sex in exchange for money [44]. Some departments will have a male officer in plainclothes posing as the "pimp" of the decoy. This allows an officer to be near the operation for safety purposes [44].

The decoy officer must try to disguise herself as a typical street level provider. The profile of providers may vary by jurisdiction, but the majority of street level providers are not dressed well, are dirty, and addicted to drugs [42]. In order to maintain their cover, street level decoys must look, act, and sound like typical providers as atypical decoys may scare buyers off [42]. Especially in street level operations, it is important for the decoy to know and use the street jargon naturally. If the decoy is not aware of the street jargon, her cover can be blown and the department will lose out on the arrest of the buyer [42].

The decoy will typically wait for a buyer to drive up and start a conversation. She will approach the vehicle and attempt to engage them. Engaging the buyer takes a certain skill that is learned over time working reverse stings [44]. The decoy may use "ego boosters," eye contact, and flattering language to keep the buyer interested [44]. The goal of the decoy is to get the transaction to meet the elements of the criminal statute. In Texas, this means the buyer must offer to engage, agree to engage, or engage in sexual conduct for a fee [36]. Video surveillance typically catches such actions when buyers try to avoid verbalizing their agreement [44]. The decoy will always try to get the buyer to verbalize since she is likely wired with a voice recording device [44]. Once the elements are met, the signal is made for the apprehension of the buyer. Some departments will formally arrest the buyer; others will try diversion programs such as "john schools" for first time offenders.

\section{Web Based Reverse Stings}

The development of the internet has moved a large portion of the commercial sex industry to the web. As such, law enforcement agencies have had to adapt their methods in order to conduct reverse stings via the internet. Web based reverse stings are becoming more and more popular $[41,43,44]$. A "web based" reverse sting is one where law

\footnotetext{
${ }^{1}$ The Waco Police Department will detain buyers and then run a criminal background search to confirm whether the individual is a first time offender. If the buyer qualifies for the diversion program, they will not be formally arrested but rather offered the opportunity to attend the Waco Police Department John School.
} 
enforcement agencies post a decoy advertisement on popular commercial sex websites advertising the purchase of $\operatorname{sex}[41,43,44]$.

The language of the ad is chosen based on common language used for ads in that given area [44]. The ads will not blatantly advertise the sale of sex but will use language common to the industry [44]. The buyer contacts the number on the ad and arranges the meet up time and location with the decoy [44]. Both calls and text messages are common methods for buyers to contact these advertisements [44]. The decoy will then arrange the meeting and the buyer will typically agree to the price and service over the telephone. The ads are placed at high frequency times, such as lunch time [44]. One Texas police department describes the initial call as "brief and basic" [44]. The buyer calls in, sometimes the agreement is made immediately, and then the buyer is given a call back time [44]. When the buyer returns the call, the decoy will give the buyer a specific spot to go to and return the call again [44]. Little by little, the buyer is given directions to the hotel room at each call back time [44]. He is not given the room number until his final call stating he is outside of the hotel location [44].

Depending on the type of web based sting that is being conducted, the decoy will use different language with the buyer in order to secure the transaction [44]. When the sting is conducted for the purposes of targeting buyers of commercial sex acts with minors, the decoy will pose as the "madam" or the female version of a pimp [44]. She will let the buyer know that the provider is actually underage [44]. Most of these types of web based stings are conducted for the purposes of targeting sex trafficking of minors directly [41, 43, 44]. When the buyer shows up at the meeting location, he is placed under arrest and charged with the applicable state and/or federal statute [44].

Most web based stings will have a hotel location as the meet up spot $[41,43,44]$. The law enforcement agency will rent at least two rooms, side by side [44]. One room will be set up for the decoy and the buyer to meet in [44]. The other will have the other officers and recording equipment [44]. The decoy room will be set up with both voice and video recording devices. The decoy will remind the buyer of the agreement, service, and price such that it is recorded properly [44]. Once the agreement is made, the officers in the other hotel room enter and place the buyer under arrest [44].

\section{Brothel Based Reverse Stings}

A brothel based sting is one in which decoys are placed as staff members within an operating brothel or sexually oriented business [43]. As defined by the legislature, an SOB "means a sex parlor, nude studio, modeling studio, love parlor, adult bookstore, adult movie theater, adult video arcade, adult movie arcade, adult video store, adult motel, or other commercial enterprise the primary business of which is the offering of a service or the selling, renting, or exhibiting of devices or any other items intended to provide sexual stimulation or sexual gratification to the customer" [46]. These are the least common type of reverse sting operation, and only twenty-five jurisdictions nationwide have reported using this type of sting operation [43]. These types of stings largely focus on arresting providers and often let the buyers go [41].

Decoys are placed within the business to investigate what activities are being bought and sold. Brothel stings that occur in nail salons or massage parlors will likely have the entire staff and survivors replaced with decoys who continue to make appointments and serve customers, at which point arrests will be made according to the sting operation [41].

\section{Case Study of the Houston Modeling Studio Reverse Sting Operation}

Many jurisdictions have been experimenting with a tactic that mixes both web based and brothel based reverse sting operations. One example of such a blending of tactics was the Houston Police Department Vice Division Modeling Studio reverse sting operation conducted in January of 2015 [47].

The operation began on January 20, 2015 and resulted in the arrest of sixty-four men for attempting to purchase sex [47]. Houston Police Department reported hundreds of men contacting the modeling studio to purchase sex [47]. The operation was staged as a web based reverse sting operation with a meeting location that was functioning as a front for a brothel. Ads were placed on popular websites known for advertising the purchase of sex. Houston Police Department rented out a physical location that appeared to be a typical storefront operating as a walk-in modeling studio. Decoy officers were placed as staff members. The buyers showed up to the studio and selected a decoy from which to purchase sex. Houston police officers then entered the studio staging a raid type sting wherein they asked for identification from the buyers within the studio. The identity of the buyers was recorded. The men were permitted to leave and then were subsequently arrested at a later date [47]. The arrests began on February 19, 2015 [48]. This set-up allowed the police department to continue the sting operation for weeks without detection from local buyers [48]. The mugshots were 
released to local news stations and media outlets. Photographs along with basic identifying information were available for the public to view [47].

Police departments often face several obstacles when trying to organize operations such as this one. One such obstacle is public backlash. The Houston Chronicle article reporting the success of the operation that was posted on the Chronicle's website had approximately 300 comments on the news story. Of these 300 comments, approximately 200 of them were negative responses to the efforts of the Houston Police Department. Only 20 of the comments posted were in support of this operation [47].

\section{National Day of Johns Arrests}

National Day of Johns Arrests is a term given to a period of time and widespread operations where law enforcement agencies across the nation concentrate efforts on reverse sting operations with the purpose to reduce demand for commercial sex [49]. The efforts began in Cook County, Illinois under the leadership of Sheriff Thomas Dart [50]. The first National Day of Johns Arrests was conducted in October of 2011 with eight participating agencies. ${ }^{2}$ As a result of the first National Day of Johns Arrests, 216 buyers and two "pimps" were arrested [51]. To date, there have been a total of nine National Day of Johns Arrests. Harris County Sheriff's Office was the first Texas law enforcement agency to participate in October of 2012 which yielded a total of ninety-four arrests for solicitation of sex, thirty-eight civil citations, seven possession of drugs arrests, two weapons arrests, and eight warrant arrests [52].

Since October, 2012, several Texas law enforcement agencies have participated in the National Day of Johns Arrests including Harris County Sheriff's Office, Houston Police Department, Harris County Constable Precinct 4, Harris County Constable Precinct 3, Bexar County Sheriff's Office, San Antonio Police Department, Texas Office of the Attorney General, Bexar County District Attorney's Office, and Texas Department of Safety. The most recent National Day of Johns Arrest was conducted in February 2015 during the weeks surrounding the Super Bowl. Thirtyseven law enforcement agencies participated nationwide. Nationally, the operations resulted in twenty-three sex trafficking and pimping arrests, 570 sex solicitation arrests of buyers, eighteen weapons seized, four narcotics arrests, and sixty-eight rescued victims [50]. Of the sixty-eight rescued victims, fourteen of them were minors [50]. These operations targeted the online market for commercial sex by posting fake ads on Backpage and Craigslist. About $64 \%$ of those arrested responded to Backpage ads [50]. Another 7\% had responded to Craigslist ads [50]. At a statewide level, the three participating Texas law enforcement agencies arrested 162 offenders [53]. Harris County Sheriff's Office arrested 100 buyers, Houston Police Department arrested forty-eight buyers, and Texas Department of Public Safety arrested fourteen buyers [53].

\section{Buyer Diversion Programs/“`John” Schools}

The term "john school" is used to describe programs designed to educate and/or treat purchasers of commercial sex [54]. Depending on the jurisdiction, the program may be a part of a roadside deterrent effort, a pre-trial diversion program, a component of a deferred adjudication agreement, or even an intervention tactic used in place of first arrest. The common goal of the program is to reduce demand through education and therapy.

\section{The One-day John School Program}

The one-day schools are typically associated with pretrial diversion programs and/or deferred adjudication requirements. ${ }^{3}$ This means that in order to successfully complete a court ordered agreement, the buyer must attend the one-day school program. Each school has a different curriculum, but most are designed to educate buyers of potential dangers of engaging in such activity, treat certain addictions typically associated with the activity of purchasing sex, and address the potential effects such activity have on personal relationships such as marriage. Currently, there are three schools in operation in Texas in Waco, Dallas, and San Antonio.

The first school in Texas was started by the Waco Police Department in 2002 [44]. The school was spear-headed by Waco Police Department Investigator Anita Johnson. She first learned of this type of program through a television show and proposed it to the Waco Police Department in 1998. At first try, the school was turned down but eventually approved and held for the first time in 2002 [44].

\footnotetext{
${ }^{2}$ The first right participating jurisdictions: Cook County Sheriff Police Department (Illinois); Aurora Police Department (Illinois); Cincinnati Police Department (Ohio); Elgin Police Department (Illinois); Las Vegas Police Department (Nevada); Los Angeles Police Department (California); Phoenix Police Department (Arizona); Newport News Police Department (Virginia).
} 
Buyers end up attending the program as a result of an agreement made with Waco police officers at the time of the custody following a successful reverse sting operation. Following the agreement between the decoy and the buyer, the buyer is taken into custody. A background search is conducted to determine whether the buyer qualifies for the option to attend the school instead of being arrested, charged, and prosecuted. If the buyer qualifies, he is offered the opportunity to pay for and attend the school without an official arrest [44]. The first school had twelve attendees; it was an all-day course with a fee of $\$ 150.00$ per attendee [44]. The original curriculum included information on drug and alcohol abuse, the dangers of contacting sexually transmitted diseases and HIV, a mandatory and free STD/HIV test, information on sex addictions, a survivor's story on the effects of prostitution in her life and the dangers to purchasers, and a Cook County Human Trafficking video presentation [44]. Later, the curriculum and cost of the school changed; the fee was changed to $\$ 350.00$ and the curriculum was altered to include a lesson on the effects of prostitution on a neighborhood as well as information on family violence [44]. The programs are scheduled and run by investigator Anita Johnson a couple weeks following every reverse sting operation. To date, the program has had 135 attendees and only three re-offenders picked up [44]. Re-offenders are arrested and processed through the criminal system without the option to attend the school. Currently, the Waco Police Department program is being revised and proposed to a nongovernmental agency to take over [44].

The Dallas S.T.O.P. Program (Solicitors, Traffickers, and Offenders of Prostitution) is held four times per year [55]. It is a one day, eight hour course that costs the buyer $\$ 250.00$ to attend [55]. Buyers that go through this program have been processed through the criminal justice system and have been referred to the program by a judge and/or as a part of a plea deal reached with the Dallas County District Attorney's Office [55]. The program is put on by a group of volunteers who work in different areas including law enforcement, criminal law, and therapy [55]. The program curriculum includes sections on the impact on the community/family/selves, impact on health, pornography and sex addictions, and the recovery process [55]. There is mandatory STD/HIV testing for each attendee. An average class will have approximately thirty-five to forty attendees [55] and the program is offered in both English and Spanish. Attendees must stay for the entire program and complete the STD/HIV blood test, in order to receive certification of completion of the program [55].

\section{Video/Online John School}

A video john school is presented in the form of a DVD to buyers being processed at the time of arrest. Although buyers are still processed through the criminal justice system, the video is an attempt to educate at point of first contact with law enforcement. This method was most notably used by Cook County Sheriff's Office in Chicago, Illinois. The sheriff's office created and produced approximately 4,000 copies of the program through a grant given by Demand Abolition. The DVD's were disseminated to law enforcement agencies to be used at point of arrest. The curriculum was designed to deter individuals from purchasing sex through educating buyers on the legal and health consequences of purchasing commercial sex [56].

An online john school is one in which is court ordered through a conviction, deferred adjudication agreement, or pre-trial diversion program. Some jurisdictions permit the offender to complete the school online and receive a certificate. The offender is ordered to take the course, pays and signs up online, and receives the certification after watching the video and completing the final examination [57].

\section{Roadside John School}

Some jurisdictions are practicing a "roadside" method to the john school tactic. The program is a condensed video presentation shown to suspected buyers in high prostitution areas that are not arrested. The goal is deterrence through preventative education and highlights the legal and health dangers associated with purchasing commercial sex.

The Tucson Police Department instituted the Safety Through Deterrence (STD) program wherein they approached suspected buyers, checked their identification, and administered the roadside video plus disbursed educational materials. Within the first five weeks of the program, 217 buyers were approached. The video and materials were disbursed, allowing the buyers to leave without being arrested. Tucson Police Department will arrest a buyer if he is

\footnotetext{
${ }^{3}$ A pre-trial diversion program is one in which the prosecution of the defendant is halted and no plea is entered. The defendant is given the opportunity to complete an ordered program or set of requisites in order to avoid prosecution. If successfully completed, the defendant avoids further prosecution. Deferred adjudication requires the defendant plead guilty or nolo contendere to the charges. That plea remains unless and until the defendant completes the requirements of the agreement. After completion, the prosecutor's office will dismiss the case. If the defendant does not complete the requirements, then the plea is entered by the court.
} 
approached a second time [58].

\section{Texas Law Authorizing John Schools}

In 2011, House Bill 1994 passed authorizing the creation of first offender prevention programs at the local level for eligible first-time prostitution and trafficking offenders. The bill defines "first offender prostitution prevention program" as a program with certain essential characteristics and sets out the powers and duties of a first offender prostitution prevention program [59]. This bill sets out eligibility for offenders to participate and grants authorization to collect a fee for the program.

In order to be an authorized program, the bill requires that the program has (1) the integration of services in the processing of cases in the judicial system; (2) the use of a non-adversarial approach involving prosecutors and defense attorneys to promote public safety, to reduce the demand for the commercial sex trade and trafficking of persons by education offenders, and to protect the due process rights of program participants; (3) early identification and prompt placement of eligible participants in the program; (4) access to information, counseling, and services relating to sex addiction, sexually transmitted diseases, mental health, and substance abuse; (5) a coordinated strategy to govern program responses to participant compliance; (6) monitoring and evaluation of program goals and effectiveness; (7) continuing interdisciplinary education to promote effective program planning, implementation, and operations; and (8) development of partnerships with public agencies and community organizations [60].

In order to be eligible to participate in first offender program, the attorney representing the state consents to the defendant's participation in the program, and the court in which the criminal case is pending finds that the defendant has not been previously convicted of a felony or previous prostitution related offense [60]. Additionally, a defendant is not eligible to participate in the program if the defendant offered or agreed to hire a minor under the age of eighteen at the time of the offense [60]. The curriculum must provide each participant with information, counseling, and services relating to sex addiction, sexually transmitted diseases, mental health, substance abuse, and classroom instruction related to the prevention of prostitution. Successful completion of the program will result in a dismissal if the defendant has not been previously convicted of a felony offense, and is not convicted of any other felony offenses before the second anniversary of the defendant's successful completion of the program [60].

\section{CONCLUSION}

At the local, state and national levels there are a number of efforts and initiatives that properly address human trafficking as a serious human rights violation. The United States government and the State of Texas are attempting to disrupt the trafficking "market" by shifting policies to address both the supply and the demand for commercial sex. Texas state legislative responses and initiatives to combat sex trafficking by reducing demand issues are being implemented and have shown to be a dedicated approach to an increasingly difficult problem.

\section{CONFLICT OF INTEREST}

The authors confirm that this article content has no conflict of interest.

\section{ACKNOWLEDGEMENTS}

CHILDREN AT RISK would like to gratefully acknowledge the Texas Bar Foundation, whose support enabled the research for this article.

\section{REFERENCES}

[1] National Human Trafficking Resource Center (NHTRC). 2014. Annual Report [Online]. Available from: http://www.traffickingresourcecenter.org/sites/default/files/2014\%20NHTRC\%20Annual\%20Report_Final.pdf

[2] Office of the Attorney General. Report to the Texas Legislature Human Trafficking Prevention Task Force. 2014; pp. 1-27. Available from: https://www.texasattorneygeneral.gov/files/agency/20142312_htr_fin.pdf

[3] Ivestopedia. Economics Basics: Supply and Demand [Online]. Available from: http://www.investopedia.com/university/economics /economics3.asp

[4] United States Department of State Office to Monitor and Combat Trafficking in Persons. Trafficking in Persons Report. 2013 ; pp. 1-66. Available from: . http://www.state.gov/documents/organization/210737.pdf

[5] H.B. 188, 2015 Leg. $84^{\text {th }}$ Sess. (Tx. 2015). Available from: http://www.capitol.state.tx.us/tlodocs/84R/billtext/pdf/HB00188F.pdf\#navpanes=0

[6] Weitzer R. sex trafficking and the sex industry: The need for evidence-based theory and legislation. J Crim Law Criminol 2011; 101(4): 
1336-70.

[7] Victims of Trafficking Act 22 USC $\$ 7109$ 2000. Available from: https://www.law.cornell.edu/uscode/text/22/7109

[8] Marcus A, Horning A, Curtis R, et al. Conflict and agency among sex workers and pimps: a closer look at domestic minor sex trafficking. Ann Am Acad Pol Soc Sci 2014; 653(1): 225-46. [http://dx.doi.org/10.1177/0002716214521993]

[9] United Nations Office on Drugs and Crime (UNODC). Global Report on Trafficking in Persons 2014 [Online] . 2015; pp. 1-90. Available from: https://www.unodc.org/documents/data-and-analysis/glotip/GLOTIP_2014_full_report.pdf.

[10] Marcus A, Riggs R, Horning A. Is child to adult as victim is to criminal?. Social Networks Research Group 2011; pp. 1-25. [Online].

[11] O’Connell-Davidson J. Will the real sex slave please stand up? Fem Rev 2006; 83: 4-22. [http://dx.doi.org/10.1057/palgrave.fr.9400278]

[12] Dank M, Khan B, Downey PM, et al. Estimating the size and structure of the underground commercial sex economy in eight major us cities. [Online]. The Urban Institute 2014. Available from: http://www.urban.org/research/publication /estimating-size-and-structure-undergroundcommercial-sex-economy-eight-major-us-cities/view/full_report 2015.

[13] Thrukal J, Ditmore M. Revolving Door. The Urban Institute 2003; pp. 1-100. [Online]. Available from: http://sexworkersproject.org/ downloads/RevolvingDoor.pdf.

[14] Benoit C, McCarthy B, Jansson M. Stigma, sex work, and substance use: a comparative analysis. Sociol Health Illn 2015; 37(3): 437-51. [http://dx.doi.org/10.1111/1467-9566.12201] [PMID: 25688450]

[15] United States Department of State Office to Monitor and Combat Trafficking in Persons. Trafficking in Persons Report [Online] 2014 2015; 1-66. Available from: http://www.state.gov/j/tip/rls/tiprpt/2014/index.htm?

[16] Thrukal J, Ditmore M. Behind closed doors: An analysis of indoor sex work in new york city [Online] The Urban Institute 2005 2015; 1-96. Available from: http://sexworkersproject.org/downloads/BehindClosedDoors.pdf

[17] Monto MA, McRee N. A comparison of the male customers of female street prostitutes with national samples of men. Int J Offender Ther Comp Criminol 2005; 49(5): 505-29.

[http://dx.doi.org/10.1177/0306624X04272975] [PMID: 16260480]

[18] Rosenberg R. Tackling the demand that fosters human trafficking. U.S. Aid 2011; pp. 1-68. Online

[19] Milrod C, Monto MA. The hobbyist and the girlfriend experience: Behaviors and preferences of male customers of internet sexual service providers. Deviant Behav 2012; 33(10): 792-810. [http://dx.doi.org/10.1080/01639625.2012.707502]

[20] Monto MA, Milrod C. Ordinary or peculiar men? Comparing the customers of prostitutes with a nationally representative sample of men. Int J Offender Ther Comp Criminol 2014; 58(7): 802-20. [http://dx.doi.org/10.1177/0306624X13480487] [PMID: 23525181]

[21] Joseph L, Black P. Who's the Man? Fragile masculinities, consumer masculinities, and the profiles of sex work clients. Men Masculinities 2012; 15: 486-506. [http://dx.doi.org/10.1177/1097184X12458591]

[22] Monto MA. Focusing on the clients of street prostitutes: A creative approach to reducing violence against women - Summary Report. [Online] US Dept of Justice 2015. https://www.ncjrs.gov/pdffiles1/nij/grants/182859.pdf.

[23] Monto MA. Female prostitution, customers, and violence. Violence Against Women 2004; 10(2): 160-88. [http://dx.doi.org/10.1177/1077801203260948]

[24] Worldvision. The trafficking victims protection act 2015. Available from: http://www.worldvision.org/resources.nsf/main/lobbying-resources /\$file/trafficking-victims-protection-act.pdf

[25] Trafficking victims protection reauthorization act of 2003,. Pub L No 108-193, 117 Stat 2875 2003. Available from: http://www.state.gov/j/tip/laws/61130.htm

[26] Trafficking victims protection reauthorization act of 2005,. Pub L No 109-164, 119 Stat 35582003 . Available from: http://www.state.gov/j/tip/laws/61106.htm

[27] William Wilberforce Trafficking Victims Protection Reauthorization Act of 2008. Pub L No 110-457, 122 Stat 5044 2003. Available from: http://www.state.gov/j/tip/laws/113178.htm

[28] William Wilberforce Trafficking Victims Protection Reauthorization Act of 2013. Pub L 113-4 110 Stat 111-118, 140, 144 , 156-159 2003. Available from: http://www.state.gov/j/tip/laws/113178.htm

[29] US v. Jungers. 702 F3d 1066, 1069 (8th Cir 2013) 2013

[30] Human Trafficking Rescue Project: Operation Guardian Angel 2009. Available from: http://www.fbi.gov/kansascity/press-releases /2009/kc031009.htm

[31] Justice for Victims Trafficking Act of 2015. 114 $4^{\text {th }}$ Congress Public Law 22. 2015. Available from: https://www.congress.gov/114/plaws/ publ22/PLAW-114publ22.pdf

[32] Shared Hope International. Justice for Victims of Trafficking Act Section-by-Section Analysis.. Available from: http://sharedhope.org/wp- 
content/uploads/2015/03Justice-for-Victims-of-Trafficking-Act-2015_Section-by-Section_Reported-...pdf 2015.

[33] Tex. Pen. Code $\S 12.22$. Available from: http://www.statutes.legis.state.tx.us/Docs/PE/htm/PE.12.htm.

[34] H.B. 10, 2015 Leg. $84^{\text {th }}$ Sess. (Tex. 2015). Available from: http://www.capitol.state.tx.us/tlodocs/84R/billtext/pdf/ HB00010F.pdf\#navpanes $=0$.

[35] In the Matter of B.W., 313 S.W.3d 819 (Tex. 2010). Available from: http://www.allcourtdata.com/law/case/in-re-bw/cGawfm6.

[36] Tex. Pen. Code $\S 12.22$. Available from: http://www.statutes.legis.state.tx.us/Docs/PE/htm/PE.12.htm.

[37] S.B. 825, 2015 Leg. $84^{\text {th }}$ Sess. (Tex. 2015). Available from: http://www.capitol.state.tx.us/tlodocs/84R/billtext/pdf/ SB00825F.pdf\#navpanes $=0$.

[38] Public information request to the Texas Department of Public Safety, (on file with the authors).

[39] Tex. Pen. Code $\S 20 A .02$. Available from: http://www.statutes.legis.state.tx.us/Docs/PE/htm/PE.20A.htm.

[40] Roe-Sepowitz DE, Gallagher J, Risinger M, Hickle K. The sexual exploitation of girls in the United States: The role of female pimps. J Interpers Violence 2015; 30(16): 2814-30. [http://dx.doi.org/10.1177/0886260514554292] [PMID: 25392377]

[41] Shively M, Kliorys K. An overview of reverse sting operations in the United States. Abt Assocs 2012; 37-8. Available from: https://www.ncjrs.gov/pdffiles1/nij/grants/238796.pdf.

[42] Dodge M, Starr-Gimeno D. Puttin' on the sting: Women police officers' perspectives on reverse prostitution assignments. Int J Police Sci Manag 2005; 7(2): 71-85. [http://dx.doi.org/10.1350/ijps.7.2.71.65778]

[43] Shively M, Kliorys K. An overview of web-based reverse stings in the United States. Abt Assocs 20132015. Available from: http://www.demandforum.net/wp-content/uploads/2012/01/web-reverse-sting-overview-national-assessment2.pdf

[44] 2015. Interview with investigator Anita Johnson, Waco police department. On file with authors.

[45] Jaffe E. Mapping the 'Demand' side of prostitution. The Atlantic CityLab [Online] 2015. Available from: http://www.citylab.com/work/ 2012/12/mapping-demand-side-prostitution/4073/

[46] Tex. Local Gov. Code $§ 243.001$. Available from: http://www.statutes.legis.state.tx.us/Docs/LG/htm/LG.243.htm

[47] Lezon D. Sex sting nabs 64 men in Houston [Online]. Houston Chronicle. Available from: http://www.chron.com/houston/ article/Sex-stingnabs-64-men-6114097.php 2015.

[48] ABC 13 Eyewitness News. 64 Men Charged in HPD. Prostitution Investigation. Available from: http://abc13.com/news/64-men-charged-inhpd-prostitution-investigation/543655/. 2015.

[49] Alter C. Cops Arrest 500 Johns in Sex Trade Crackdown. [Online]. Time Magazine. Available from: http://time.com/3083244/sex-traffickingprostitution-national-day-of-johns-arrests/ 2015.

[50] Demand Abolition. Available from: http:/www.demandabolition.org/national-day-of-johns-arrests/

[51] Bilecki F. Press release- cook county, Illinois, announces results of first-ever nationally coordinated sting operation to arrest johns and mute demand for prostituted individuals. Cook County Sherriff's Off 2011 2015. Available from: http://www.demandabolition.org/wpcontent/uploads/2011/10/release_dayofjohnsarrests1.pdf

[52] Press Release Columbus Day 2012 Law Enforcement Agencies across the Nation Continue to Target "Johns" 2015. Available from: http://www.demandabolition.org/wp-content/uploads/2012/10/NDJA_columbus_day.pdf

[53] Cook County Sheriff's Office. 570 Sex Buyers Arrested in National Super Bowl Sting Operation 2015. Available from: http://www.cookcountysheriff.org/press_page/press_SuperbowlSting_02_02_2014.html

[54] Shively M, Kliorys K. An overview of john schools in the United States. Abt Assocs 2012; pp. 1-28. [Online].

[55] 2015. Interview with renee breazeale, program manager, dallas county district attorney's office community, prosecution division

[56] Cook County Sheriff's Office. Press Release- Championship Numbers Tell Sad Story 2012. Available from: http://www.cookcounty sheriff.org/press_page/press_ChampionshipNumbers_02_07_12.html

[57] First Offender Prostitution Program. Logan Social Services. Available from: http://www.loganinstitute.com/index.php.

[58] Wallace JD. Tucson police use education to drive away prostitution. 2015 [Online] Tucson News . Available from: http://www.tucsonnewsnow.com/story/1888941/tucson-police-use-education-to-drive-away-prostitution

[59] Weber R. Bill Analysis. [Online]. House Criminal Justice Committee. 2011. Available from: http://www.capitol.state.tx.us/tlodocs/82R/ analysis/html/HB01994H.htm 2011 . 
[60] H.B. No. 19942011 Leg. 82 ${ }^{\text {nd }}$ Sess. (Tex. 2011). Available from: http://www.capitol.state.tx.us/tlodocs/82R/billtext/pdf/ HB01994F.pdf\#navpanes $=0$.

(C) Brautigam et al.; Licensee Bentham Open.

This is an open access article licensed under the terms of the Creative Commons Attribution-Non-Commercial 4.0 International Public License (CC BY-NC 4.0) (https://creativecommons.org/licenses/by-nc/4.0/legalcode), which permits unrestricted, non-commercial use, distribution and reproduction in any medium, provided the work is properly cited. 